\title{
BAROTRAUMA TELINGA TENGAH (MIDDLE EAR BAROTRAUMA)
}

\section{Astri Sumandari}

Fakultas Kedokteran, Universitas Mataram, Indonesia

Email: astrisumandari751@gmail.com

\begin{abstract}
Abstrak
Barotrauma terjadi pada banyak penyelam di dunia termasuk di Indonesia. Insiden barotrauma cukup banyak di Indonesia terutama pada penyelam tradisional. Hal tersebut dikarenakan penyelam tradisional umumnya kurang memperhatikan halhal yang berhubungan dengan keselamatan dan kesehatan kerja, sehingga berpotensi terkena barotrauma telinga tengah Tujuan dari penulisan ini adalah untuk mengetahui terkait dengan barotrauma telinga tengah yang meliputi definisi, epidemiologi, penyebab dan faktor risiko, diagnosis, hingga tatalaksana dan juga pencegahan yang dapat dilakukan. Telinga manusia terdiri dari 3 bagian utama, yaitu telinga luar, telinga tengah dan telinga dalam. Salah satu cedera yang dapat mengenai bagian telinga manusia adalah barotrauma. Barotrauma adalah cedera yang disebabkan oleh perbedaan tekanan antara ruang internal dan eksternal tubuh. Barotrauma dapat terjadi pada setiap struktur tubuh, dimana terdapat ruang tertutup yang dapat ditempati oleh udara, antara lain ruang telinga tengah, sinus, paru-paru, lambung dan usus. Namun, barotrauma paling sering terjadi di telinga tengah, yang terutama disebabkan oleh rumitnya fungsi tuba Eustachius. Barotrauma telinga tengah terjadi ketika tuba Eustachius tidak dapat dibuka untuk menyeimbangkan tekanan udara. Dalam berbagai literatur dilaporkan bahwa insiden dan prevalensi barotrauma telinga berkisar antara 4,1 - 82\%. Manifestasi klinis pada barotrauma telinga tengah berupa kurang dengar, rasa nyeri dalam telinga, autofoni, perasaan ada air dalam telinga dan kadang-kadang disertai tinitus dan vertigo.
\end{abstract}

Kata kunci: Barotrauma; Barotrauma Telinga Tengah; Penyelam.

\section{Abstract}

Barotrauma occurs in many divers in the world including in Indonesia. Barotrauma incidents are quite numerous in Indonesia, especially in traditional divers. This is because traditional divers generally pay less attention to things related to occupational safety and health, so they are potentially exposed to middle ear barotrauma. The purpose of this writing is to find out related to middle ear barotrauma which includes definition, epidemiology, causes and risk factors, diagnosis, to governance and also prevention that can be done.The human ear consists of 3 main parts, there are the outer ear, middle ear and inner ear. One of the injuries that can affect the human ear is barotrauma. Barotrauma is an injury caused by a pressure difference between the inside of the body and the external space. Barotrauma can occur in any structure in the body where there is an enclosed space that can be occupied by air including the middle ear space, paranasal sinuses, lungs, stomach and intestines. However, barotrauma most commonly occurs in the middle ear, this is mainly due to the complexity of the 
function of the eustachian tube. Middle ear barotrauma occurs when the eustachian tube cannot open to balance air pressure. In various literatures it is reported that the incidence and prevalence of ear barotrauma ranges from $4.1-82 \%$. Clinical manifestations of middle ear barotrauma include hearing loss, pain in the ear, autophony, a feeling of water in the ear and sometimes accompanied by tinnitus and vertigo.

Keywords: Barotrauma; Middle Ear Barotrauma; Diver

Diterima: 13-12-2021 Direvisi: 10-01-2022 Diterbitkan: 20-01-2022

\section{Pendahuluan}

Telinga manusia terdiri dari 3 bagian utama, yaitu telinga luar, telinga tengah dan telinga dalam (Sherwood, 2001). Telinga tengah berisi rongga timpani berisi udara, ruang tidak teratur di tulang temporal antara membran timpani dan permukaan tulang telinga bagian dalam. Bagian depan ruang berkomunikasi dengan faring melalui tabung pendengaran (tabung eustachius atau tuba eustachius), dan bagian belakang berkomunikasi dengan rongga mastoid berisi udara dari tulang temporal (Azka, 2018).

Salah satu cedera yang dapat mengenai bagian telinga manusia adalah barotrauma. Barotrauma merupakan cedera yang disebabkan oleh perbedaan tekanan antara didalam tubuh dengan ruang eksternal (Kaplan, 2017). Barotrauma dapat terjadi pada setiap struktur tubuh, dimana terdapat ruang tertutup yang dapat ditempati oleh udara, antara lain ruang telinga tengah, sinus, paru-paru, lambung dan usus (Arbanto et al., 2018). Namun, barotrauma paling sering terjadi di telinga tengah, yang terutama disebabkan oleh rumitnya fungsi tuba Eustachius. Barotrauma telinga tengah terjadi ketika tuba Eustachius tidak dapat dibuka untuk menyeimbangkan tekanan udara (Martinus et al., 2019).

Dalam berbagai literatur dilaporkan bahwa insiden dan prevalensi barotrauma telinga berkisar antara 4,1 - 82\% (Ariani et al., 2020). Barotrauma terjadi pada banyak penyelam di dunia termasuk di Indonesia. Insiden barotrauma cukup banyak di Indonesia terutama pada penyelam tradisional. Hal tersebut dikarenakan penyelam tradisional umumnya kurang memperhatikan hal-hal yang berhubungan dengan keselamatan dan kesehatan kerja, sehingga berpotensi terkena barotrauma telinga tengah (Martinus et al., 2019).

Data yang di kumpulkan DepKes. R.I dari 10 Propinsi sampai dengan tahun 2008, sebanyak 93,9\%, dari 1.028 penyelam tradisional yang di wawancarai secara langsung di temukan penyakit dengan gejala klinis akibat penyelaman. 39,7\% diantaranya mengalami gangguan pendengaran ringan sampai ketulian (Sugianto et al., 2017). Tujuan dari penulisan ini adalah untuk mengetahui terkait dengan barotrauma telinga tengah yang meliputi definisi, epidemiologi, penyebab dan faktor risiko, diagnosis, hingga tatalaksana dan juga pencegahan yang dapat dilakukan. 


\section{Metode Penelitian}

Metode yang digunakan dalam penulisan tinjauan pustaka ini yaitu dengan literature review, menggunakan literature searching. Pencarian Pustaka menggunakan alat bantu cari berbasis website yaitu Google, Google Scholar dan PubMed menggunakan kata kunci Barotrauma telinga dan Middle Ear Barotrauma. Publikasi berbahasa Inggris maupun Indonesia free full text. Total jurnal yang dipilih dalam literature review ini yaitu sebanyak 5 jurnal (Soelistyarini, 2013).

\section{Hasil dan Pembahasan}

\section{A. Definisi dan Epidemiologi}

Barotrauma telinga adalah cedera jaringan pada telinga yang terjadi akibat pemerataan tekanan yang tidak memadai antara ruang tubuh yang berisi gas dan lingkungan eksternal. Dalam berbagai literatur dilaporkan bahwa insiden dan prevalensi barotrauma telinga berkisar antara 4,1 - 82\% (Ariani et al., 2020). Barotrauma terjadi pada banyak penyelam di dunia. Prevalensi barotrauma mencapai 0,35\% dari 10.000 penyelaman yang dilakukan dengan angka kematian mencapai 1,3\% dari 10.000 penyelam. Angka kejadian barotrauma cukup tinggi di Indonesia. Kejadian barotraumaa telinga mencapai 11,3\% di pulau bunging (Salma et al., 2021). Data yang di kumpulkan DepKes. R.I dari 10 Propinsi sampai dengan tahun 2008, sebanyak 93,9\%, dari 1.028 penyelam tradisional yang di wawancarai secara langsung di temukan penyakit dengan gejala klinis akibat penyelaman. 39,7\% diantaranya mengalami gangguan pendengaran ringan sampai ketulian (Sugianto et al., 2017).

\section{B. Etiologi dan Faktor Risiko}

Etiologi yang mendasari barotrauma adalah perbedaan tekanan antara ruang telinga tengah dan lingkungan eksternal. Apabila tekanan melebihi $90 \mathrm{mmHg}$, tuba eustachius tidak dapat terbuka (Arbanto et al., 2018). Sesuai hukum boyle, peningkatan tekanan ambien menghasilkan penurunan volume gas yang proporsional di ruang tubuh. Peningkatan tekanan ambien ini dapat terjadi ketika seseorang melakukan penyelaman, berada di pesawat terbang, ruang hiperbarik atau karena trauma benda tumpul. Selain itu terdapat beberapa kondisi yang menjadi faktor risiko terjadinya barotrauma pada telinga tengah yaitu riwayat kanker kepala dan leher, saluran koklea yang membesar atau lebih pendek, saluran vestibular yang membesar serta kondisi anatomis telinga tengah dan telinga dalam (Sumarna et al., 2018).

\section{Patofisiologi}

Perbedaan tekanan yang ada memnyebabkan terjadinya tekanan negatif pada ruang telinga tengah sehingga terjadi peningkatan aliaran darah melalui pembuluh subkutan pada saluran telinga luar, membran timpani, tuba eustchacius dan telinga tengah. Hal tersebut menyebabkan pembengkakan pada pembuluh darah (Hafli, 2019). Saat tekanan terus meningkat, pembuluh darah tersebut akhirnya pecah dan menyebabkan perdarahan ke dalam atau di belakang membran timpani. Jika dibiarkan berlanjut, peningkatan tekanan ambien pada akhirnya akan mengakibatkan perforasi 
membran timpani dan komplikasi yang terkait. Tekanan pasti yang dibutuhkan untuk memecahkan membran timpani masih belum jelas, tetapi diperkirakan sekitar $100 \mathrm{kPA}$.

\section{Diagnosis}

Manifestasi klinis pada barotrauma telinga tengah berupa kurang dengar, rasa nyeri dalam telinga, autofoni, perasaan ada air dalam telinga dan kadang-kadang disertai tinitus dan vertigo (Fitri, n.d.). Selain itu, pasien juga perlu ditanyakan terkait riwayat pajanan terhadap perubahan tekanan ambien atau trauma. Namun pada beberapa pasien terkadang tidak menunjukkan gejala apapun (asimtomatik). Setelah pasien memiliki tanda dan gejala barotrauma telinga, selanjutnya dilakukan evaluasi lebih lanjut melalui pemeriksaan otoskopi untuk menentukan dan mengklasifikasikan tingkat cedera. Pemeriksaan ini penting karena akan membantu penegakkan diagnosis dan pengobatan yang akan diberikan. Saat ini, ada tiga metode untuk mengevaluasi dan menilai barotrauma telinga tengah yaitu sistem penilaian Teed, Modified Teed, dan O'Neill. Sistem klasifikasi ini lebih sering digunakan pada komunitas bawah laut dan hiperbarik, sistem ini tidak sering digunakan oleh ahli THT.

Salah satu metode untuk mengklasifikasikan tingkat cedera pada barotrauma telinga adalah Teed Grading. Teed Grading mengevaluasi potensi trauma terhadap membran timpani yang dievaluasi satu kali oleh pemeriksa. Berikut klasifikasinya:

> Grade 0: Membran timpani normal

$>$ Grade 1: Retraksi TM dengan kemerahan di sepanjang manubrium malleus

$>$ Grade 2: Sama seperti Grade 1 ditambah retraksi TM dengan kemerahan di seluruh TM

$>$ Grade 3: Sama seperti grade 2 ditambah adanya cairan di timpanum atau hemotympanum

$>$ Grade 4: Perforasi membran timpani

\section{E. Tatalaksana}

Pengobatan konservatif barotrauma telinga biasanya cukup, yaitu dengan memberikan dekongestan lokal atau melakukan manuver Valsava, selama tidak ada infeksi saluran pernapasan atas. Jika cairan atau cairan bercampur darah tetap berada di telinga tengah selama beberapa minggu, dianjurkan untuk melakukan miringotomi dan menggunakan selang ventilasi jika diperlukan. Prosedur miringotomi ini secara klasik dilakukan di bagian anterior dan inferior membran timpani untuk menghindari potensi kerusakan pada struktur telinga tengah, terutama bila dilakukan secara darurat dalam kasus yang ekstrim. Komplikasi yang dapat terjadi terkait dengan prosedur ini yaitu infeksi, perdarahan, gangguan pendengaran dan perforasi kronis (Hafli, 2019).

Saat ini diketahui ada 4 cara menyeimbangkan tekanan di rongga telinga tengah yaitu: (1) dengan menggerakkan rahang ke kiri dan ke kanan, (2) meniup perlahan dengan lubang hidung tertutup (teknik Valsava) (3) menelan ludah (metode Toynbee) dan (4) menguap (Arbanto et al., 2018). Usaha preventif terhadap barotrauma dapat dilakukan dengan selalu mengunyah permen karet atau melakukan perasat Valsalva, terutama sewaktu pesawat terbang mulai turun untuk mendarat. Beberapa studi mengatakan bahwa pra-pengobatan dengan pseudoefedrin dapat menurunkan risiko 
barotrauma selama perjalanan udara pada orang dewasa. Selain itu penggunaan pseudoefedrin sebelum menyelam dapat menurunkan insiden dan keparahan barotrauma telinga tengah pada penyelam. Namun penggunaan obat-obatan tersebut perlu diperhatikan terkait efek samping yang ditimbulkan (Hafli, 2019).

\section{F. Komplikasi}

Komplikasi yang dapat terjadi akibat dari barotrauma telinga yaitu efusi serosa, efusi serosanguinosa, perdarahan pada telinga tengah, perforasi membran timpani dan barotrauma telinga dalam (inner ear barotrauma). Selain itu dapat terjadi gangguan pendengaran yang bersifat sementara sampai kronis, infeksi telinga tengah, nyeri kronis, serta gangguan kestabilan gaya berjalan (gangguan keseimbangan) dan kelumpuhan saraf (Aquinas, 2017).

\section{Kesimpulan}

Barotrauma merupakan cedera yang terjadi akibat perbedaan tekanan antara ruang eksternal dan bagian dalam tubuh. Barotrauma dapat terjadi di setiap struktur tubuh, termasuk ruang tertutup yang dapat ditempati oleh udara, tetapi paling sering terjadi di telinga tengah. Manifestasi klinis barotrauma telinga tengah termasuk gangguan pendengaran, sakit telinga, dering spontan, sensasi air di telinga, dan terkadang tinnitus dan pusing. Pengobatan barotrauma telinga biasanya cukup konservatif, yaitu tanpa adanya infeksi saluran pernapasan atas, diberikan dekongestan lokal atau manuver Valsava. Anda dapat mencegah barotrauma dengan sering mengunyah permen karet atau melakukan manuver Valsava, terutama saat pesawat mulai turun dan mendarat. 


\section{BIBLIOGRAFI}

Aquinas, R. (2017). Talakasana Otitis Media Efusi pada Anak. Cermin Dunia Kedokteran, 44(7), 472-477. Google Scholar

Arbanto, B., Putra, K. P., \& Al Ardha, M. A. (2018). Perbedaan tingkat keberhasilan 3 metode ekualisasi pada penyelam terlatih di lingkungan air tawar. Jurnal Keolahragaan, 6(2), 193-199. Google Scholar

Ariani, R., Annisa, M. K. T., Muhammad Edy Syahputra Nasution, S.-K., Sinaga, N., Pratiwi, F. D., Nanda Nuralita, S. K. J., Yunafri, A., An, S., Chalil, M. J. A., \& An, S. (2020). Ragam Penanganan dan Pencegahan COVID-19 di Rumah Sakit dan Klinik Primer (Vol. 1). umsu press. Google Scholar

Azka, R. (2018). Gambaran Tingkat Personal Hygiene Pada Pasien Apendisitis Anak. Google Scholar

Fitri, W. S. (n.d.). Uji diagnostik otoendoskop dibandingkan Dengan pemeriksaan otoskop langsung Pada siswa Kelas Sdn Cirendeu. Fakultas Kedokteran Universitas Islam Negeri Syarif Hidayatullah Jakarta. Google Scholar

Hafli, A. F. (2019). Buku Ajar Ilmu Kesehatan: Telinga Hidung Tenggorokan Kepala dan Leher. Google Scholar

Kaplan, J. A. (2017). Kaplan's Essentials of Cardiac Anesthesia E-Book. Elsevier Health Sciences. Google Scholar

Martinus, I., Hadisaputro, S., \& Munasik, M. (2019). Berbagai Faktor yang Berpengaruh terhadap Barotrauma Telinga Tengah pada Penyelam Tradisional (Studi di Wilayah Balaesang Tanjung Kabupaten Donggala). School of Postgraduate. Google Scholar

Salma, W. O., La Ode Muhammad Yasir Haya, S. T., Binekada, I. M. C., Repro, M., Onk, S. B. K., \& La Ode Alifariki, S. K. (2021). Buku Referensi Potret Masyarakat Pesisir Konsep Inovasi Gizi \& Kesehatan. Deepublish. Google Scholar

Sherwood, L. (2001). Fisiologi manusia dari sel ke sistem. Google Scholar

Soelistyarini, T. D. (2013). Pedoman Penyusunan Tinjauan Pustaka dalam Penelitian dan Penulisan Ilmiah. Universitas Airlangga. Google Scholar

Sugianto, S., Hadisaputro, S., Supriharti, S., Munasik, M., \& Adi, M. S. (2017). Beberapa Faktor yang Berpengaruh terhadap Barotrauma Membran Timpani pada Penyelam Tradisional di Wilayah Kabupaten Banyuwangi. Jurnal Epidemiologi Kesehatan Komunitas, 2(1), 27-35. Google Scholar

Sumarna, U., Sumarni, N., \& Rosidin, U. (2018). Bahaya Kerja Serta Faktor-faktor yang Mempengaruhinya. Deepublish. Google Scholar 
First publication right:

Jurnal Syntax Fusion: Jurnal Nasional Indonesia

This article is licensed under:

@ (1) ( 